\title{
NILAI TAMBAH DAN SALURAN PEMASARAN IKAN JULUNG-JULUNG (Hemirhamphus Sp) ASAP DI DESA BUAJANGKA KECAMATAN BUNGKU SELATAN KABUPATEN MOROWALI PROVINSI SULAWESI TENGAH
}

\section{ADDITIONAL VALUE AND MARKETING OF JULUNG-JULUNG FISH (Hemirhamphus sp.) MARKETING FISH IN BUAJANGKA VILLAGE, SOUTH BUNGKU DISTRICT, MOROWALI DISTRICT CENTRAL SULAWESI PROVINCE}

\author{
Ahsan Mardjudo ${ }^{1 *}$, Ade Ayu ${ }^{1}$ \\ ${ }^{1}$ Program Studi Agrobisnis Perikanan, Fakultas Perikanan, Universitas Alkhairaat \\ Jl. Diponegoro No. 39, Palu 94221, Sulawesi Tengah, Indonesia
}

\begin{abstract}
ABSTRAK
Penelitian bertujuan untuk mengetahui proses pengasapan ikan julung-julung (lokal: ikan roa) dan nilai tambah dari pengolahan pengasapan, serta mengetahui saluran pemasaran ikan roa di desa Buajangka Kecamatan Bungku Selatan Kabupaten Morowali Provinsi Sulawesi Tengah. Pengambilan data dalam penelitian ini dilakukan dengan metode sensus kepada seluruh masyarakat yang melakukan usaha pengasapan ikan julung-julung (ikan roa) di Desa Buajangka. Analisis data melalui pendekatan deskriptif kualitatif dan kuantitatif. Hasil penelitian ini menunjukkan bahwa secara teknis proses pengasapan ikan roa dimulai dari penerimaan bahan baku, pencucian, pengangkutan, penjepitan dan pengikat jepit, penataan, proses pengasapan, dan pengemasan atau pengepakan. Nilai tambah yang di hasilkan dari usaha pengasapan ikan roa di Desa Buajangka Kecamatan Bungku Selatan dalam per gepe (jepit) ikan roa asap adalah Rp.6.082. Nilai Tambah yang dihasilkan dari usaha pengasapan ikan roa di daerah penelitian tergolong rendah dengan rasio nilai tambah > 50\% (40,54 \%). Sementara saluran pemasaran usaha pengasapan ikan roa menjual langsung produk ikan roa asap kepada konsumen dan pedagang pengumpul yang berasal dari luar daerah seperti Kendari, Bungku Tengah, Tentena, Poso dan Palu yang datang langsumg di tempat usaha pengasapan ikan roa.
\end{abstract}

Kata kunci: Nilai tambah; saluran pemasaran; ikan julung-julung asap

\section{ABSTRACT}

This research aims to find out the fumigation process (local: roa fish)and the added value of fumigation processing, and knowing the marketing channels for roa fish in Buajangka village, South Bungku District of Morowali regency in Central Sulawesi Province. Data collection in this research was carried out by census method to all people who conduct fumigation of smoked-baffled fish (roa fish) in Buajangka Village. The data were analysis through qualitative and quantitative descriptive approaches. The research results show that technically, the fumigation process for roa fish starts from receiving raw materials, washing, transporting, clamping and fixing clips, structuring, fumigation process, and packaging or packing. The added value generated from the cocoa fumigation business in Buajangka Village, South Bungku District in per bunch of roa fish is Rp. 6,082. The added value generated from the cocoa fumigation business in the study area was relative low with a value added ratio> $50 \%$ (40.54\%). While the marketing channel of Roa's fish fumigation business sells smoked roa fish products directly to consumers and collectors who come from outside the region such as Kendari, Bungku Tengah, Tentena, Poso and Palu who come directly to the place of roa fumigation.

Keywords: added value; marketing channel; smoked-baffled fish

\footnotetext{
${ }^{*}$ Penulis Korespondensi

E-mail : ahsan.mardjudo@gmail.com

Telp: 082192416776
} 


\section{Pendahuluan}

Kabupaten Morowali adalah salah satu kabupaten yang memiliki potensi sumberdaya perikanan tangkap. Dengan lokasi sentral pengolahan ikan di Desa Buajangka berupa pengasapan ikan roa/julung-julung (Hemirhampus, sp.). Ikan julung-julung ini merupakan salah satu sumberdaya ikan pelagis yang terdapat di Desa Buajangka Kecamatan Bungku Selatan Kabupaten Morowali. Ikan roa/julung-julung (Hemirhampus, sp.) merupakan salah satu produk ikan asap yang bernilai jual cukup tinggi dan menjadikan produk olahan, produk ini banyak diminati oleh masyarakat (Badan Pusat Statistik Kabupaten Morowali, 2017).

Mengolah komoditas perikanan laut yang ada di Desa Buajangka Kecamatan Bungku Selatan Kabupaten Morowali yang bertujuan untuk meningkatkan pendapatan serta untuk memenuhi kebutuhan rumahtangga, masyarakat yang berada di wilayah tersebut menjalankan usaha pengasapan ikan roa/julung-julung (Hemirhampus, sp.). Usaha ini masih menggunakan peralatan dan perlengkapan yang masih sangat sederhana. Menurut (Santoso, 2000), dalam tehnik pengasapan ini dengan menggunakan beberapa cara dalam pelaksanaanya, cara-cara tersebut diawali dengan penyediaan peralatan dan perlengkapan, penerimaan bahan baku, pencucian, penjepitan bahan baku, proses pengasapan langsung, pengepakan dan diakhiri dengan sistem pemasaran.

Secara sosial ekonomi ikan sangat penting bagi kehidupan masyarakat, sebagai contoh di daerah sekitar pesisir yaitu di Desa Buajangka Kecamatan Bungku Selatan Kabupaten Morowali Sulawesi Tengah, dimana hampir semua penduduknya menggantungkan hidupnya pada usaha penangkapan dan pengolahan ikan. Pengolahan pengasapan ikan bertujuan untuk mempertahankan mutu awet ikan serta mendapatkan nilai tambah terhadap hasil tangkapan.

Hal ini menjadi dasar pertimbangan penulis untuk melakukan penelitian tentang nilai tambah dan saluran pemasaran pengasapan ikan roa (Hemirhampus sp.) di Desa Buajangka Kecamatan Bungku Selatan Kabupaten Morowali Sulawesi Tengah.

Nilai tambah adalah merupakan pertambahan nilai suatu komoditas karena mengalami proses pengolahan, pengangkutan ataupun penyimpanan dalam suatu proses produksi. Sedangkan saluran pemasaran merupakan salah satu sistem agribisnis yang aktivitas ekonominya menghubungkan antara produksi dan konsumen. Produk sebagai hasil dari kegiatan produksi harus menguntungkan produsen yang berada pada titik produksi dan harus memenuhi kebutuhan dan keinginan konsumen yang berada pada titik konsumsi (Heriansyah, 2004).

Berdasarkan uraian di atas, maka dirumuskan masalah antara lain yaitu (1) Bagaimana proses pengasapan ikan julungjulung/roa (Hemirhampus sp.) yang ada di Desa Buajangka Kecamatan Bungku Selatan Kabupaten Morowali Propinsi Sulawesi Tengah; (2) Berapa besar nilai tambah yang diperoleh usaha pengolahan pengasapan ikan julungjulung/roa (Hemirhampus sp.); dan (3) Bagaimana saluran pemasaran ikan asap julungjulung/roa (Hemirhampus sp.) Adapun tujuan penelitian adalah (1) Untuk mengetahui proses pengasapan ikan julung-julung/roa (Hemirhampus sp.) di Desa Buajangka Kecamatan Bungku Selatan Kabupaten Morowali; (2) Untuk mengetahui nilai tambah dari pengolahan pengasapan ikan julungjulung/roa (Hemirhampus sp.); dan (3) Untuk mengetahui saluran pemasaran pengolahan pengasapan ikan julung-julung/roa (Hemirhampus sp.).

\section{Metode Penelitian}

\section{Landasan Teori}

Ikan Julung-julung (Hemirhampus sp.) hidup dalam gerombolan besar, dilapisan permukaan, kadar garam tinggi, dapat mencapai panjang $45 \mathrm{~cm}$, umumnya $30 \mathrm{~cm}$. Ikan Julungjulung Tergolong ikan pelagis yang hidup di lapisan atas atau permukaan, penangkapan dengan soma antoni, jala, soma giob, dipasarkan dalam bentuk segar, asin-kering atau asapan kering. Ikan ini merupakan salah satu jenis ikan ekonomis penting karena memiliki rasa yang gurih dan sangat diminati oleh pasar apalagi untuk produk ikan julung-julung asap, sehingga harganya juga tetap stabil (Simbolon, 2011).

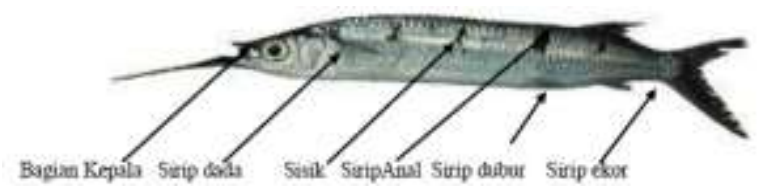

Gambar 1. Ikan Julung-julung (Hemirhampus sp.) Kotelate, (1993) 
Morfologi Bentuk tubuh berbentuk pipih memanjang seperti silindris atau pipa. Kepala bersisik, rahang bawah lebih panjang dari rahang atas dan bagian ujungnya, bibir tipis. Gurat sisi sempurna, memanjang mulai dari bawah tutup insang dan berakhir dipertengahan pangkal sirip ekor, tidak membentuk rigi pada batang ekor. Ikan ini pada umumnya berkumpul dekat permukaaan air dan melompat ke luar air menurut Saanin (1984).

Pengasapan adalah salah satu cara pengolahan ikan yang dapat dilakukan dengan peralatan yang sederhana dan mudah didapat serta murah harganya. Ikan yang diolah dengan cara pengasapan dapat menjadi awet disebabkan oleh beberapa faktor, diantaranya adalah berkurangnya kadar air ikan sampai dibawah $40 \%$, adanya senyawa-senyawa didalam asam kayu yang menghambat pertumbuhan mikroorganisme pembusuk dan terjadinya koagulasi protein pada permukaan ikan yang mengakibatkan jaringan pengikat menjadi lebih kuat dan kompak sehingga tahan terhadap serangan dari mikroorganisme.

Menurut Murniyati dan Sunarman (2000) pengasapan dapat dilakukan dengan dua cara, yaitu pengasapan panas (hot smoking) dan pengasapan dingin (cold smoking), namun dewasa ini seiring dengan perkembangan jaman pengasapan juga bisa dilakukan dengan pengasapan elektrik serta pengasapan cair (liquid).

Tabel 1. Perbedaan pengasapan panas dan pengasapan dingin

\begin{tabular}{llcl}
\hline $\begin{array}{c}\text { Jenis } \\
\text { pengasapan }\end{array}$ & Temperatur & Waktu & Daya awet \\
\hline $\begin{array}{l}\text { Pengasapan } \\
\text { dingin }\end{array}$ & $40-50^{\circ} \mathrm{C}$ & $1-2$ minggu & $\begin{array}{l}2-3 \text { minggu } \\
\text { sampai bulan }\end{array}$ \\
\hline $\begin{array}{l}\text { Pengasapan } \\
\text { panas }\end{array}$ & $70-100^{\circ} \mathrm{C}$ & Beberapa jam & Beberapa hari \\
\hline Sumber $:($ Murniyati dan Sunarman 2000) &
\end{tabular}

Sumber : (Murniyati dan Sunarman, 2000)

Secara umum nilai tambah (value added) dapat didefinsikan kegiatan atau langkahlangkah dalam proses yang menambah atau mengubah suatu produk atau jasa. Informasi atau pengeluaran yang diperoleh dari hasil analisis nilai tambah adalah besarnya nilai tambah dan rasio nilai tambah. Berdasarkan pengertian tersebut, perubahan nilai bahan baku yang telah mengalami perlakuan pengolahan. Besar nilainya dapat diperkirakan (Hayami, et al. 1987).

Nilai tambah suatu produk merupakan hasil dari nilai produk akhir dikurangi dengan biaya antara yang terdiri dari biaya bahan baku . makin besar nilai komponen biaya antara yang digunakan maka nilai tambah produk tersebut makin kecil (Mangifera, 2015). Dalam proses pengolahan nilai tambah dapat didefinisikan sebagai selisih antara nilai produk dengan nilai biaya bahan baku dan input lainnya, tidak termasuk tenaga kerja. Pertambahan nilai komoditas karena mengalami proses pengolahan , pengangkutan dan penyimpanan.

Nilai tambah yang semakin besar atas produk perikanan khususnya ikan tentunya dapat berperan bagi peningkatan pertumbuhan ekonomi. Pertumbuhan ekonomi yang tinggi tentu saja berdampak bagi peningkatan lapangan usaha dan pendapatan masyarakat. Nilai tambah juga dapat digunakan untuk mengukur tingkat kemakmuran masyarakat setempat dengan asumsi seluruh pendapatan itu dinikmati masyarakat setempat (Nurhayati, 2004).

Nilai tambah produk dapat didefinisikan adalah pertambahan nilai suatu komoditas karena mengalami proses pengolahan, pengangkutan ataupun penyimpanan dalam suatu produksi. Dalam proses pengolahan nilai tambah produk sebagai selisih antara nilai produk dengan nilai biaya bahan baku dan input lainnya, tidak termasuk tenaga kerja(Hayami, et al. 1987).

\section{Lokasi Penelitian}

Penelitian ini dilaksanakan di Desa Buajangka Kecamatan Bungku Selatan Kabupaten Morowali Propinsi Sulawesi Tengah. Penentuan tempat penelitian ini berdasarkan atas pertimbangan bahwa di Desa Buajangka Kecamatan Bungku Selatan Kabupaten Morowali memiliki potensi sumberdaya ikan roa/julungjulung (Hemirhampus sp.) yang bernilai ekonomi untuk pengolahan ikan asap.

\section{Metode Pengambilan Data}

Jenis data yang dikumpulkan dalam penelitian ini adalah meliputi data primer dan data sekunder. Data primer adalah data yang dikumpulkan melalui pengamatan langsung di lapangan untuk mendapatkan keterangan secara jelas dan terinci, dan wawancara mendalam dengan menggunakan kuesioner. Jenis data primer yang dikumpulknan meliputi data proses produksi, biaya-biaya yang digunakan dalam proses produksi, dan saluran pemasaran ikan julung-julung (lokal: ikan roa). Sedangkan data sekunder adalah data yang diperoleh melalui teori dari beberapa literatur untuk dijadikan sumber pustaka yang berkaitan dengan objek penelitian ini serta data dari beberapa instansi terkait. 


\section{Metode Analisis Data}

Untuk menjawab tujuan pertama dan ketiga digunakan analisis deskriptif dengan metode tabulasi, proses produksi, dan saluran pemasaran ikan julung-julung, sedangkan tujuan kedua di analisis dengan pendekatan perhitungan nilai tambah menggunakan peralatan analisis (Hayami, 1987):

$$
\mathrm{NT}=\mathrm{NP}-(\mathrm{NBB}+\mathrm{NBP}+\mathrm{NPP})
$$

Keterangan :

NT : Nilai Tambah Ikan Roa (Rp/Kg)

NP : Biaya Produk (Rp/produksi)

NBB : Biaya Bahan Baku $(\mathrm{kg})$

NBP : Biaya Bahan Penunjang (Rp/produksi)

NPP : Biaya penyusutan alat (Rp/produksi).

Secara matematis rasio nilai tambah usaha pengolahan ikan roa/julung-julung Di Desa Buajangka Kecamatan Bungku Selatan yaitu sebagai berikut:

Ratio Nilai Tambah $=\frac{\text { NT } \times 100 \%}{\text { NP }}$

Keterangan :

NT : Nilai Tambah

NP : Nilai Produk

\section{Hasil dan Pembahasan}

\section{Aspek Teknis Usaha Pengasapan Ikan Julung- Julung (Hemirhampus sp.)}

Di bawah ini kami uraikan langkahlangkah teknis dalam proses pengolahan ikan asap antara lain sebagai berikut:

\section{Penerimaan Bahan Baku}

Bahan baku yang digunakan dalam usaha pengolahan ikan asap di Desa Buajangka masih segar dan belum di awetkan dan harus bermutu tinggi.Hal ini sesuai degan pendapat Moeljanto (1992) bahwa untuk memperoleh produk yang bermutu maka bahan baku yang dipakai juga harus bermutu tinggi, diantaranya ikan yang masih dalam keadaan segar serta perlakuan suhu rendah dengan memperhatikan faktor kebersihan dan kesehatan.

\section{Pencucian}

Bahan baku ikan yang didalam bak kapal dipindahkan di keranjang tanpa menggunakan alat apapun melainkan langsung dipindahkan dengan menggunakan tangan telanjang. Kemudian keranjang yang sudah terisi ikan dicelupkan ke dalam air laut untuk dicuci dan tidak menggunakan loyang sebagai wadah untuk tempat pencucian bahan baku.

\section{Pengangkutan}

Bahan baku yang terisi di keranjang yang sudah dicuci kemudian diangkut oleh dua orang tenaga kerja tanpa menggunakan gerobak hingga sampai di tempat pengasapan, dengan jarak tempuh kurang lebih sekitar 30 meter. Bila bahan baku berasal dari daerah lain akan ditambahkan es untuk menjaga kesegaran ikan tersebut. Menurut (Mareta dan Awami, 2011) baik atau buruknya mutu ikan sebenarnya ditentukan oleh kesempurnaan penanganan ikan, dalam penanganan ikan segar bertujuan agar kesegaran ikan dapat tetap terjaga dan dapat dipertahankan selama atau setidaknya hingga ikan sampai ke tangan konsumen dan salah satu cara mengawetkan ikan yang tidak merubah sifat alami ikan adalah pendinginan dan pembekuan.

\section{Penjempitan dan Pengikat Jepit}

Bahan baku yang telah diangkut sampai di rumah pengolah langsung dilakukan penjepitan. Proses penjempitan menggunakan tenaga kerja yang jumlahnya berkisar 5-6 orang yang melakukan penjempitan bahan baku. Bahan penjepit yang digunakan terbuat dari bambu dengan bagian ukuran panjang penjepit yaitu $70 \times 3 \mathrm{~cm}$ dan lebar penjepit $30 \times 3 \mathrm{~cm}$. Hal ini sesuai dengan yang dipaparkan oleh ((Munandar, 2008), bahwa bahan penjepit yang digunakan terbuat dari bambu dengan bagian ukuran panjang penjepit yaitu $70 \times 3 \mathrm{~cm}$ dan lebar penjepit $30 \times 3 \mathrm{~cm}$, sehingga penggunaan bahan penjepit bambu bertujuan agar ikan dapat dilakukan proses pengasapan dengan mudah dan aman. Dalam proses ini bahan baku harus cepat dijepit guna mengurangi laju kerusakan atau laju pembusukan yang disebabkan oleh suhu ruangan, cacat fisik karena bahan baku tidak menggunakan bahan pembantu seperti es dan garam.

Bahan baku yang telah dilakukan penjepitan dan telah melalui tahap pengikatan, kesegaran ikan terus mengalami penurunan karena suhu ruang yang tinggi serta proses perlakuan yang lambat. Untuk mengurangi laju proses pembusukan pada langkah penjepitan dan pengikatan jepitan memang sangat dibutuhkan orang yang mahir, karena dalam proses pejepitan bahan baku ikan julung-julung dalam jumlahnya banyak, agar proses penururnan mutu dapat diminimalisir.

\section{Penataan}

Bagi ikan yang sudah di jepit dan di ikat di tata dengan cara meletakkan di atas para-para. Pada tahap pertama ikan disusun secara vertikal 
yaitu bagian kepala ikan menghadap ke bawah. Pada tahap kedua, posisi ikan dibalik yaitu bagian kepala menghadap ke atas, untuk bertujuan mengurangi turunnya kadar air dan aktivitas air yang terkandung dalam daging ikan pada saat pengasapan. Hal ini sesuai dengan pendapat (Kanoni $d k k .$, 1991) bahwa dalam proses penataan untuk pengasapan bahan baku pada tahap disusun secara vertikal dimulai dari kepala yang menghadap ke bawah. Pada tahap kedua, posisi ikan dibalik yaitu bagian kepala menghadap ke atas, agar memudahkan daging ikan menyerap partikel-partikel asap serta mendapatkan aliran asap dan panas yang merata, jarak antara ikan-ikan pada rak pengasap dan jarak antara masing-masing rak pengasapan dalam ruang pengasapan tidak boleh terlalu rapat.

\section{Proses Pengasapan}

Berdasarkan pengamatan dan deskripsi alat pengasapan yang digunakan untuk proses pengolahan ikan julung-julung asap adalah jenis alat pengasapantertutup yaitu berbentuk seperti rumah terdapat dua ruangan utama, karena usaha pengasapan ini merupakan usaha pengasapan ikan yang masih tradisional dan berskala rumahtangga. Proses pengasapan bahan baku ikan julung-julung adalah salah satu proses apakah produk akan memperoleh hasil yang baik atau buruk, dengan tidak melupakan faktor-faktor pendukung seperti bahan bakar, waktu pengasapan, suhu pengasapan, volume asap dan teknik.

Simko (2005) menyatakan bahwa jenis kayu yang digunakan ialah jenis kayu yang keras, seperti kayu batang kelapa, kayu bakau dan tempurung kelapa sebagai bahan bakar, karena jenis kayu keras tersebut tidak cepat habis sertamengandung senyawa phenol dan asam organik yang cukup tinggi dan sangat dibutuhkan untuk proses pengasapan. Usaha pengolahan ikan asap ini bertempat di Desa Buajangka Kecamatan Bungku Selatan Kabupaten Morowali Provinsi Sulawesi Tengah. Tergolong usaha pengolahan ikan asap yang masih sangat tradisional dalam peralatan dan perlengkapan yang masih sangat sederhana. Hal ini sesuai dengan pendapat (Swastawati 2011) bahwa proses pengasapan ikan di indonesia pada mulanya masih dilakukan secara tradisional serta menggunakan peralatan yang sederhana.

Untuk proses pengasapan khusus bahan baku ikan julung-julung menggunakan teknik pengasapan panas dan teknik pengasapan dingin dan lama waktu pengasapan terbagi atas beberapa tahap. Tahap pertama berlangsung selama \pm 46jam mulai dari jam 18.00 -23.00 wita, kemudian pengasapan tahap ke dua dilakukan dimulai pada pagi hari selama \pm 4-7 jam mulai dari jam 07.0013.00 wita. Waktu proses pengaspan yang digunakan peneliti sesuai pendapat (Damonglala, 2009) bahwa waktu yang digunakan padatahap pertama dalam proses pengasapan berlangsung dimana ikan diasapi di letakan cukup dekat dengan sumber asap. Suhu sekitar $70-100^{\circ} \mathrm{C}$. Lamanya pengasapan 2-4 jam. kemudian pengasapan tahap ke dua dilakukan dimulai pada pagi hari selama \pm 3-6 jam mulai dari jam 08.0013.00 dengan kisaran suhu $\pm 50-70^{\circ} \mathrm{C}$. Pada tahap pertama ikan disusun secara vertikal yaitu bagian kepala ikan menghadap ke bawah. Pada tahap kedua, posisi ikan dibalik yaitu bagian kepala menghadap ke atas. Selanjutnya ikan dipindahkan ke rak kedua yang letaknya $\pm 1 \mathrm{~m}$ di atas rak pertama Selama pengasapan berlangsung, waktu dan penggunaan bahan bakar selaludiperhatikan karena baik dan buruknya hasil pengasapan sangat tergantung dari penggunaan bahan bakarnya.

Uraian tersebut di atas, sesuai dengan pendapat (Abu, 2008) bahwa kisaran suhu proses pengasapan tidak lebih dari $100^{\circ}$ Ckarena pada proses pengasapan tidak bisa menggunakan suhu yang terlalu panas karena akan memengaruhi hasil pengasapan ikan. Dalam proses pengasapan ikan harus di jaga dan selalu disiram memakai air apabila apinya terlalu tinggi. Hal ini akanberpengaruh jika suhu yang digunakan terlalu tinggi yaitu bagian kulit ikan akan keriput, daging ikan akan rapuh dan warna tidak mengkilap terang.

\section{Hasil Pengasapan}

Hasil pengasapan ikan julung-julung memiliki karakteristik daging lebih kering, warna mengilap kuning keemasan, renyah (gurih) serta memiliki rasa khas ikan julung-julung asap jika sudah diolah. Berdasarkan hasil penelitian (Tadanugi, 2004) bahwa nilai kadar air ikan julung-julung asap adalah 16,20\%, hasil ini menunjukkan bahwa kadar air ikan julungjulung asap lebih rendah dari kadar air ikan asap yang dikeluarkan oleh SNI yaitu 60\%. Tidak jauh berbeda dengan hasil pengasapan (produk) usaha pengasapan ikan roa/julung-julung di Desa Buajangka Kecamatan Bungku Selatan Kabupaten Morowali, karena jika ditinjau secara produk ikan julung-julung memiliki daging lebih kering, tekstur renyah, kenampakan berwarna 
kuning keemasan, aroma dan rasa khas ikan julung-julung asap.

\section{Pengemasan/Pengepakan}

Hasil produk dari pengasapan adalah ikan asap kering yang nantinya akan dilakukan pengepakan dalam bentuk ikat, tidak menggunakan bahan pengepak seperti halnya dos melainkan hanya menggunakan tali rafia.Pengepakan yang dilakukan untuk produk ikan roa/ julung-julung (Hemirhampus sp.) asap hanyalah sesuai pesanan konsumen dan untuk pemasaran biasanya hanya bentuk ikat. Satu ikat produk ikan julung-julung matang berjumlah 10 jepit dengan setiap jepit terdapat 20 ekor ikan julung-julung asap yang sudah matang, sehingga total dalam satu ikat/pak yaitu 200 ekor.

Untuk lebih jelasnya proses pengolahan ikan roa/julung-julung (Hemirhampus sp.) yang digunkan dalam usaha pengolahan pengasapan ikan Di Desa Buajangka Kecamatan Bungku Selatan dapat dilihat pada Gambar 2.

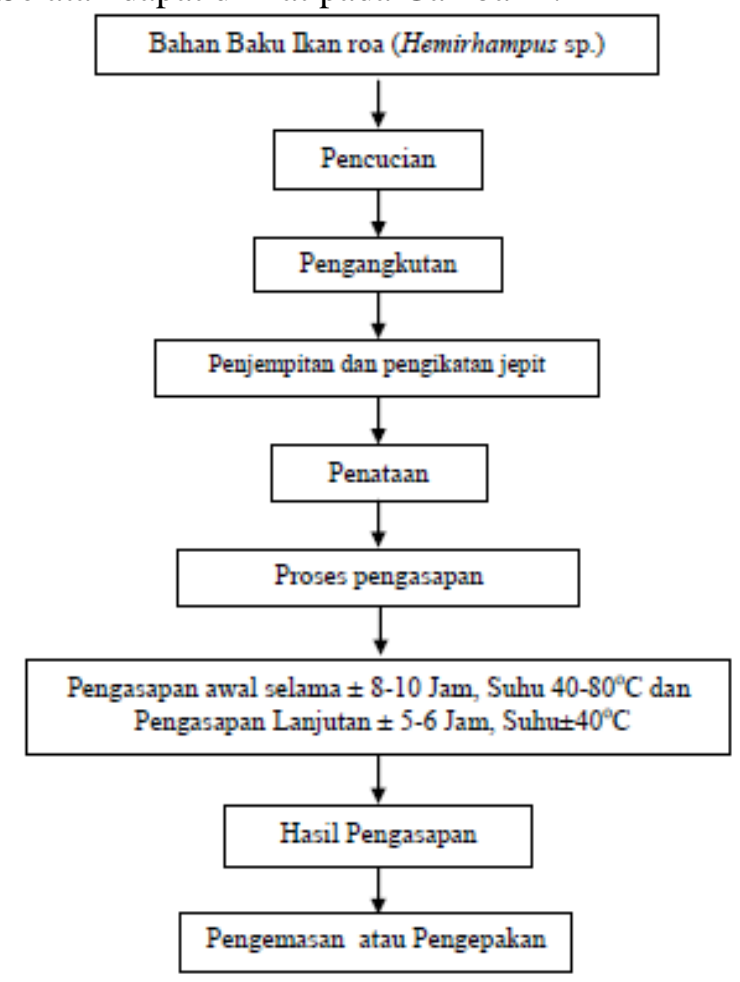

Gambar 2. Bagan Alur pembuatan ikan asap

\section{Aspek Ekonomis Usaha Pengasapan Ikan Julung-Julung (Hemirhampus, Sp)}

\section{Biaya Produksi}

Dalam usaha pengasapan ikan roa memiliki biaya yang meliputi biaya tetap (Fixed cost) dan biaya tidak tetap (Variable cost). Biaya tetap adalah biaya yang nilainya diperhitungkan tetap yaitu upa kariawan dan biaya penyusutan.
Sedangkan biaya tidak tetap adalah semua biayabiaya yang nilainya tergantung pada kebutuhan saat produksi berlangsung. Adapun total biaya produksi yang digunakan sebagai berikut :

Total Biaya = Biaya Tetap + Biaya Tidak Tetap

$$
\begin{aligned}
& =\text { Rp.26.981.666+Rp.31.661.666 } \\
& =\text { Rp.58.643.332. }
\end{aligned}
$$

\section{Produksi}

Produksi dalam usaha pengasapan ikan roa, berdasarkan hasil penelitian bahwa dalam satu kali produksi mencapai 10 pak dengan harga penjualan Rp. 150.000/pak. Dalam satu bulan produksi menghasilkan 80 pak dan dalam satu tahun produksi menghasilkan 560 pak.

\section{Pendapatan}

Total penerimaan yang diperoleh usaha pengasapan ikan roa yang ada di DesaBuajangka Kecematan Bungku Selatan. Untuk mengetahui total penerimaan dapat dilihat pada perhitungan tiap responden sebagai berikut :

a. Produksi Ikan Roa

$$
\begin{aligned}
\text { TR } & =\text { Price X Quantiti } \\
& =\text { Rp. 150.000x10 pak/produksi } \\
& =\text { Rp. 1.500.000/produksi }
\end{aligned}
$$

Berdasarkan hasil perhitungan diatas maka diketahui penerimaan dalam satu kali produksi pada usaha pengasapan ikan roa sebesar Rp. 1.500.000, dalam seminggu penghasilan mencapai Rp. 3.000.000, dan dalam sebulan sebesar Rp. 12.000.000., total penghasilan dalam setahun Rp. 84.000.000.

\section{Nilai Tambah}

Metode analisis yang digunakan untuk mengetahui nilai tambah yang diperoleh dari usaha pengasapan ikan roa/ julung-julung (Hemirhampus sp.) di Desa Buajangka Kecamatan Bungku Selatan dalam penelitian ini adalah metode perhitungan nilai tambah yaitu nilai produk dikurang dengan nilai bahan baku dan nilai bahan penunjang lainnya serta biaya penyusutan peralatan.Nilai tambah diperoleh dari proses pengolahan ikan roa /julung-julung (Hemirhampus sp.) sampai menjadi produk olahan. Output (produk olahan) yang dihasilkan pada proses ini adalah ikan roa asap. Adapun Perhitungan nilai tambah yang dilakukan pada proses usaha pengasapan ikan roa/ julung-julung (Hemirhampus sp.) Di Desa Buajangka Kecamatan Bungku Selatan sebagai berikut :

$$
\begin{aligned}
\mathrm{NT} & =\mathrm{NP}-(\mathrm{NBB}+\mathrm{NBP}+\mathrm{NPP}) \\
& =\text { Rp. } 15.000-(\text { Rp. } 7500+\text { Rp. } 348+\text { Rp. } 1.070 \\
& =\text { Rp. } 15.000-\text { Rp. } 8,918
\end{aligned}
$$


$=$ Rp. $6.082 /$ produksi

Nilai tambah pada usaha Pengasapan ikan roa di Desa Buajangka Kecamatan Bungku Selatan adalah sebesar Rp. 6.082 per gepe. Besarnya nilai tambah ini diperoleh dari pengurangan nilai produk sebesar Rp.15.000/pak dengan biaya bahan baku (harga input) sebesar Rp. $7.500 / \mathrm{Kg}$, dan biaya bahan penunjang sebesar Rp.340, serta biaya penyusutan sebesar Rp.1.070.Secara matematis rasio nilai tambah usaha pengasapan ikan julung-julung yaitu sebagai berikut:

$$
\begin{aligned}
& \text { Rasio Nilai Tambah }=\frac{\text { Rp. } 6.082}{--------} \text { x 100\% } \\
& =\text { Rp. } 15.000
\end{aligned}
$$

Besarnya nilai tambah yang diperoleh sejalan dengan besarnya rasio nilai tambah terhadap nilai produknya. Rasio nilai tambah ini diperoleh dari pembagian antara nilai tambah dengan nilai produk yang dinyatakan dalam persen (\%). Rasio nilai tambah ini menunjukkan persentase nilai tambah dari nilai produk, artinya jika rasio nilai tambah $>50 \%$ maka nilai tambah tergolong tinggi, sedangkan jika rasio nilai tambah $\leq 50 \%$, maka nilai tambah tergolong rendah. Rasio nilai tambah yang diperoleh dalam usaha pengasapan ikan julung-julung adalah $40,54 \%$ artinya rasio nilai tambah tergolong rendah.

\section{Saluran Pemasaran}

Saluran pemasaran dapat digambarkan oleh jumlah tingkat saluran pemasaran, setiap pialang atau broker (individu ataupun perusahaan) yang melaksanakan berbagai tugas mengalihkan produk dan hak pemiliknya lebih dekat kepada konsumen akhir adalah sebuah tingkat saluran. Saluran pemasara usaha pengasapan ikan roa/ julung-julung (Hemirhampus, sp.) usaha pengasapan ikan asap roa desa Buajangka kecamatan Bungku Selatan termasuk dalam saluran dua tingkat. Lebih jelasnya dapat dilihat Gambar 3.

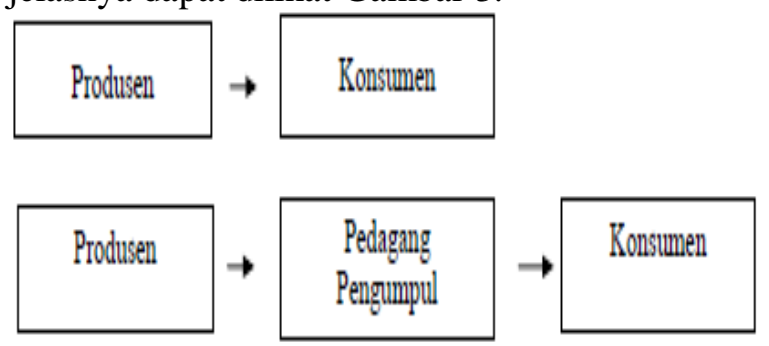

Gambar 3. Skema Saluran Pemasaran (data diolah 2018)
Dari hasil penelitian usaha pengasapan ikan roa/ julung-julung (Hemirhampus, sp.) di Desa Buajangka Kecamatan Bungku Selatan melalui Saluran pemasaran diatas dikatakan saluran dua tingkat. Usaha pengasapan ikan roa menjual langsung produk ikan roa asap kepada konsumen dan pedagang pengumpul yang berasal dari luar daerah seperti Kendari, Bungku Tengah, Tentena, Poso dan Paluyang datang langsumg di tempat usaha pengasapan ikan roa/ julung-julung (Hemirhampus, sp.).

\section{Kesimpulan}

Berdasarkan hasil penelitian yang dilakukan pada Usaha Pengasapan Ikan roa/ julung-julung (Hemirhampus, sp.) yang ada di Desa Buajangka Kecamatan Bungku Selatan Kabupaten Morowali Provinsi Sulawesi Tengah maka dapat disimpulkan sebagai berikut:

1. Besar modal yang digunakan pada usaha pengasapan ikan roa/ julung-julung (Hemirhampus, sp.) berjumlah Rp. 96.606.000,- hasil produksi dalam sekali pengasapan dapat mencapai 10 pak dengan rata-rata penjualan adalah Rp. 150.000/pak, sedangakan dalam sebulan melakukan pengasapan ikan sebanyak 8 kali dan 56 kali produksi dalam setahun, maka dengan demikian rata-rata penjualan dalam sebulan adalah Rp. 12.000.000,- dan setahun dapat mencapai Rp. 84.000.000,-.

2. Data hasil penelitian menunjukan adalah sebesar 1,4 yang artinya usaha layak untuk dijalankan, apabila dilihat dari B/C ratio nya maka usaha pengasapan ikan roa/ julungjulung (Hemirhampus sp.) di Desa Buajangka layak untuk dijalakan dan dapat dikembangkan. Untuk nilai Break Event Point (BEP) hasilnya sebesar Rp. 38.545.237 (BEP dalam Rupiah) dan 359 jepit (BEP dalam unit produksi).

3. Nilai tambah yang di hasilkan dari usaha pengasapan ikan roa/ julung-julung (Hemirhampus, sp.) di Desa Buajangka Kecamatan Bungku Selatan dalam per gepe ikan roa asap adalah Rp. 6.082. Nilai Tambah yang dihasilkan dari usaha pengasapan ikan roa di daerah penelitian tergolong rendah dengan rasio nilai tambah $>50 \%(40,54 \%)$.

4. Pemilik usaha pengasapan ikan julungjulung (Hemirhampus sp.) menjual hasil produksinya kepada konsumen dan pedagang pengumpul yang berasal dari 
berbagai daerah. Pedagang pengumpul yang datang langsung membeli di tempat pengolahan akan menjual kembali kepada konsumen ke berbagai daerah.

\section{Daftar Pustaka}

Abu F., 2008. Tekhnik Pengasapan Ikan dan Jenis-Jenis Pengasapan. Bumi Aksarah. Jakarta

Damonglala, L. 2009. Kadar Air dan Total Bakteri pada Ikan Roa (Hemirhampus sp.) Asap dengan Metode Pencucian Bahan Baku Berbeda. Jurnal Ilmiah Sains Vol. 9 No. 2

Hayami, Y. 1987, Pertanian Pemasaran dan Pengolahan Di Jawa Upland A Perspektif Dari Desa Sunda, Pusat CGPRT, Bogor.

Heriansyah, 2004. Prospek Pengembangan Agribisnis Ikan Asap di Kecamatan Sinjai Timur Kabupaten Sinjai. Tesis. Tidak dipublikasikan.

Kanoni, S., Naruki, S., dan Suhardi. 1991. Evaluasi Sifat Fisik, Laporan Penelitian. Penelitian Proyek Peningkatan Pe nelitian dan Pengabdian Pada Masyarakat. Fakultas Teknologi Pertanian. UGM. Yogyakarta.

Kotelate, 1993. Taksonomi Ikan Julung-Julung (Hemirhampus sp.).

Mareta dan Awami, 2011. Diktat Kuliah Penanganan Hasil Perikanan. Departemen
Teknologi Hasil Perairan, Fakultas Perikanan dan Ilmu Kelautan. IPB. Bogor

Murniyati dan Sunarman, 2000. Tekhnik Pengasapan Ikan. Penebar Swadaya. Jakarta.

Moeljanto, 1992. Teknik Penanganan Ikan. Penebar Swadaya. Jakarta

Nurhayati, P. 2004. "Nilai tambah produk olahan perikanan pada industri perikanan tradisional di DKI Jakarta"

Saanin, 1984. Morfologi Ikan Roa/ Julung-Julung (Hemirhampus sp.). Institut Pertanian Bogor.

Santoso, 2000. Analisis Mutu Bahan Baku. Penebar Swadaya. Jakarta

Simbolon, 2011. Penyebaran dan Keragaman Populasi Ikan Roa/Julung-Julung (HemirhampusSp)

Simko, P. 2005. Kombinasi Pelepah, Sabut dan Tempurung Kelapa Sebagai Bahan Bakar Alternatif Untuk Julung-julung (Hemiramphus sp.) Asap. Skripsi. Fakultas Perikanan dan Ilmu Kelautan. Universitas Sam Ratulangi. Manado.

Swastawati, 2011. Pengolahan Ikan Secara Tradisional : Prospek Dan Peluang Pengembangan. Pusat Riset Pengolahan Produk dan Sosial Ekonomi Kelautan Dan Perikanan Jakarta. 